Article | Philosophy of Education

\title{
The Overcoming of Violence: Paulo Freire on the Use of Violence for Social Transformation
}

\section{Franz Giuseppe F. Cortez}

\begin{abstract}
This paper explores the thoughts of Paulo Freire regarding the use of violence to attain social transformation. Contrary to some commentators, I argue that Freire's take on the role of armed struggle has taken a developmental mode. He has moved from a reformist to a revolutionary to a more critical stance. In other words, there is a movement of the overcoming of violence. The starting point of this evolution of his educational and political thinking is mainly reflected in his first book Education as the Practice of Freedom where he was convinced that social transformation follows smoothly from a "conscientized" populace. The next turning point is expressed in the pages of Pedagogy of the Oppressed where he was radical in saying that reality is not changed by changing the consciousness but by deliberately acting to change that reality. It implies further that the use of violence cannot be discarded as a remote possibility. Finally, the overcoming of violence is lucidly manifested in Learning to Question, where Freire contends that social transformation is not only gained by taking of power of the state because power permeates in the diverse elements of the state itself. In other words, power is located in small and probably, unexpected spaces. The critical educator must be sensitive enough to locate, recognize, communicate, and grab those cracks and openings.
\end{abstract}

Keywords: Freire, violent revolution, education, power

(c) 2016 Franz Giueseppe F. Cortez

http://www.kritike.org/journal/issue_19/cortez_december2016.pdf

ISSN 1908-7330 


\section{Introduction}

7 he critical educators who want to bring Freirean liberating pedagogy ${ }^{1}$ inside the classroom is confronted with the crucial question: "By adapting and adopting Paulo Freire, are we instigating our students to advocate as well a violent means to attain social transformation?" The question is pertinent because Freire is usually associated with revolutionary Marxism along with the revolutionary activities of Latin America. Moreover, Marxism in its entirety is also commonly (but wrongly) associated with totalitarian and authoritarian governments. ${ }^{2}$ Thus, the sound of a Freirean drum inside a classroom may increase what Peter McLaren, a North American activist educator, would call as "knee-jerk Marxophobia." 3 Stephen Brookfield, an authority in critical adult education, explains this Marxophobia as fear of even mentioning Marx as if by talking about the bearded man, one engages in a blasphemous and unpatriotic behavior while simultaneously advocating genocidal, repressive, totalitarian, and authoritarian regimes. ${ }^{4}$

The main aim of this paper is directed to the question and the concern mentioned above. Hence, it specifically asks: What is the stance of Freire on the use of violence to attain societal transformation? The answer to this question appears to be easy and categorical if one will consult at least three Freirean disciples. Donaldo Macedo, Freire's close friend and Ana "Nita" Araujo-Freire, Freire's second wife, declare in one essay that Freire,

... never spoke, nor was he ever an advocate, of violence or of the taking of power through the force of arms. He was always, from a young age, reflecting on education and engaging in political action mediated by an educational practice that can be transformative. He fought and had been fighting for a more just and less perverse society, a truly democratic one, one where there

\footnotetext{
${ }^{1}$ For sustained discussions on Freirean liberating pedagogy, see the following: F.G.F. Cortez, "The Prospect of Liberating Pedagogy in the Thoughts of Amable G. Tuibeo," in Mabini Review, 3:1 (2014): 16-69; F.G.F. Cortez, "The Philippine Engagement with Paulo Freire," in Kritike, 7:2 (2013): 50-70; F.G.F. Cortez, Towards a Freirean Liberating Pedagogy in the Philippines: Prospects in Three Filipino Intellectuals (Ph.D. Dissertation, Manila: University of Santo Tomas, 2013).

2 For some discussions on the differences between Marx and Marxism, see the following: Tom Rockmore, Marx after Marxism: The Philosophy of Karl Marx (Oxford: Blackwell Publishers Ltd., 2002); Peter Worsley, Marx and Marxism (London: Routledge, 2002).

${ }^{3}$ Peter McLaren, Life in Schools: An Introduction to Critical Pedagogy in the Foundations of Education, 3rd ed. (New York: Longman, 1997), 172.

${ }^{4}$ Stephen Brookfield, The Power of Critical Theory for Adult Learning and Teaching (New York: Open University Press, 2005), 19.
}

(c) 2016 Franz Giueseppe F. Cortez http://www.kritike.org/journal/issue_19/cortez_december2016.pdf ISSN 1908-7330 
are no repressors against the oppressed, where all can have a voice and a chance. ${ }^{5}$

Furthermore, Peter McLaren, believing that Freire personally abhors violence, accepts the explanation of Macedo and Araujo-Freire. Seeing an affinity of Freire's position on violence to that of Martin Luther King's and Cezar Chavez's, McLaren says that "a serious difference between Freire and Che (Guevarra) was their perspective on violence." 6

However, I will argue that Freire's take on the role of armed struggle has taken a developmental mode. He has moved from a reformist to a revolutionary to a more critical stance. In other words, there is a movement of the overcoming of violence. To defend this claim, I will consult both his texts and the various commentaries that have risen out of engagement with his works.

This paper is significant on at least three grounds. On the theoretical level, I join the Freirean scholars who insist on Freire being more of a humanist Marxist and less of a scientific Marxist. ${ }^{7}$ On the practical level, I see these explanatory insights about Freire as an opportunity for educators and students not to shy away from Freirean pedagogy but rather to re-consider its main tenets especially in an admittedly post-revolutionary society yet paradoxically, oppression has remained more ubiquitous. Indeed, there should be less rational justification to fear the bearded men: Marx and Freire. Finally, it is contributory for the sustained attempt of Freirean scholars to argue that the Brazilian philosopher's thoughts cannot be reduced to the pages of Pedagogy of the Oppressed. To put in another way, it would be misleading for Freirean scholars to be fixated with his magnum opus while the gems of his other works are simply relegated to the background.

This paper has three main sections. The first discusses Freire's reformist stance which is basically reflected in his first main work, Education

\footnotetext{
${ }^{5}$ Ana Maria Araujo-Freire and Donaldo Macedo, Introduction to Paulo Freire, The Paulo Freire Reader, ed. by Ana Maria Araujo-Freire and Donaldo (New York: Continuum, 1998), 21.

${ }^{6}$ Peter McLaren, Che Guevara, Paulo Freire, and the Pedagogy of Revolution (Lanham: Rowman \& Littlefield Publishers, 2000), 174.

7 For a thorough discussion on the difference between scientific Marxism and humanist/Western Marxism, see the following: Alvin Gouldner, The Two Marxisms: Contradictions and Anomalies in the Development of Theory (New York: The Seabury Press, 1980); Ronald Aronson, After Marxism (London: Guilford Press, 1995); Virgilio Abad Ojoy, Marxism and Religion: A Fusion of Horizons: A Discourse on Gustavo Gutierrez's Theology of Liberation and the Philippines' Church of the Poor (Manila, Philippines: UST Publishing House, 2001).
}

(C) 2016 Franz Giueseppe F. Cortez

http://www.kritike.org/journal/issue_19/cortez_december2016.pdf

ISSN 1908-7330

(c) ) BY-NC-ND 
as the Practice of Freedom (1965). The second section explores his ready approval of violent revolution that can be deduced from his works during exile, most especially in his famous book Pedagogy of the Oppressed (1970). The third section unearths his critical stance through his thoughts on the rediscovery of power best represented by his comments in the book Learning to Question (1989). I end with some concluding remarks.

\section{Education as the Practice of Freedom: Freire's Reformist Stance}

It is unknown to many that Freire's first major work is not Pedagogy of the Oppressed. Rather, it is Education as the Practice of Freedom. ${ }^{8}$ On this text, he observes that the Brazilian society is in a crucial transition from a closed to an open society, terms that he borrowed from Karl Popper. ${ }^{9}$ The historical moment was an exciting one for Brazil which became independent and democratic. Yet, most of the people were illiterate and voiceless. Worse, they are submerged in what Freire would call as magical or naïve consciousness. His aim is that through literacy education, these people who were the main victims of colonialism and exploitation will have active participation in the new society. The task of the people in this type of society is not just to adapt but to integrate themselves to it. The integrated person is a subject, living a truly human existence while the adapted person is an object, living an animal life. ${ }^{10}$ Literacy efforts through dialogical education must be a tool for the demise of a naïve consciousness and for the emergence of a critical consciousness. Through education, the victimized majority would become active participants in the new democratic society. Education is a tool for the democratization of culture. ${ }^{11}$ Through educational reforms, there would be manifest improvement in the miserable lot of the Brazilian populace. Thus, on this text, Freire contends that changing the consciousness of the oppressed people would somewhat be adequate to have meaningful changes in their socio-economic condition. ${ }^{12}$

8 This was written while Freire was jailed in Brazil after the military coup of 1964. It was first published in Chile in 1967. Later, in 1973, Freire published this in English as one of the two essays of the book Education for Critical Consciousness.

9 Paulo Freire, "Education as the Practice of Freedom," in Education for Critical Consciousness, trans. by Myra Bergman Ramos (New York: The Seabury Press, 1973). 8. Henceforth cited as, EPF.

${ }^{10}$ Ibid., 4.

${ }^{11}$ Paul V. Taylor, The Texts of Paulo Freire (Philadelphia: Open University Press, 1993),

51.

${ }^{12}$ A few years later, Freire would admit that this was a naïveté on his part. In fact, he admits that his main aim for publishing Education as the Practice of Freedom is so that his readers would know his formerly naïve stance. See Denis Goulet, Introduction to Freire, EPF, vii.

(C) 2016 Franz Giueseppe F. Cortez

http://www.kritike.org/journal/issue_19/cortez_december2016.pdf

ISSN 1908-7330

(cc) BY-NC-ND 


\section{THE OVERCOMING OF VIOLENCE}

Paulo Freire is famously and correctly labeled as a disciple of Karl Marx. Yet, the pages of Education as the Practice of Freedom would reveal that he was not a Marxist from the start. He was just eventually converted to Marxism. The said text does not contain any citation or mention of Marx. ${ }^{13}$ Rather, this text is replete of quotations from and references to the tradition of liberal education and politics. Names such as Karl Jaspers, Martin Buber, Teilhard de Chardin, Alfred Whitehead, and Jacques Maritain were very prominent in the said work.

The young Freire was more of a liberal and reformist educator rather than a radical and Marxist one. There was no manifest reference to the intrinsic link between politics and education. This was also noticed by John Elias in his attempt to explain the liberal democratic politics of the young Freire. Elias notes that Freire's liberal reformist stance was due to his "involvement with a liberal reformist government, his connection with liberal Brazilian scholars, and his reading of European and North American liberal academics." 14 The same conclusion is reached by John Holst who later described Education as the Practice of Freedom as "informed by liberal developmentalist outlook." ${ }^{15}$ Daniel Schugurensky, in another book, affirmed the position of Elias and Holst. ${ }^{16}$

Some commentators even suggested that during his stint as an education official for the Brazilian government, Freire would deliberately evade Marxist jargon. Elias comments that as far as Freire's first book is concerned, he "shows an awareness of the existence of classes but does not speak of class struggles." 17 In his unpublished dissertation, Peter Lownds quoted Vanilda Paiva who suggested that Freire would even change a Marxist term into a Jaspersian jargon-a proof that the young Freire was more of an existentialist humanist in the mold of Jaspers and Gabriel Marcel rather than a Marxist one. It is noteworthy to quote in length Vanilda Paiva.

Freire intended to extract people's truth; at the same time, he oriented the debates to specific objectives. An example of this is his belief that [the Marxist term] 'mass' should be changed to 'the people,' according to the definitions of [Karl] Jaspers. If we peruse the material available from the pre-1964 [Freire-] method literacy

${ }_{13}$ This was also observed by John Elias. See John Elias, Paulo Freire: Pedagogue of Liberation (Florida: Krieger, 1994), 33.

${ }^{14}$ Ibid., 33.

${ }^{15}$ John Holst, "Paulo Freire in Chile, 1964-1969: Pedagogy of the Oppressed in Its Sociopolitical Economic Context," in Harvard Educational Review, 76 (2006), 243.

${ }^{16}$ Daniel Schugurensky, Paulo Freire (London: Continuum, 2011), 69.

${ }^{17}$ Elias, Paulo Freire: Pedagogue of Liberation, 33.

(c) 2016 Franz Giueseppe F. Cortez

http://www.kritike.org/journal/issue_19/cortez_december2016.pdf ISSN 1908-7330

(c) BY-NC-ND 
courses, we observe that the alfabetizandos frequently refer to the fact that they are no longer a mass (massa), but rather a povo (people). A graduate of the Angicos classes said exactly this in a speech to the President of the Republic [João Goulart]. Such an idea does not come spontaneously from the people. It has to be imported from outside, brought in by the coordinators, and coincides exactly with Freire's thought. ${ }^{18}$

Taking into consideration Education as the Practice of Freedom and the subsequent commentaries regarding it, we can deduce that Freire was never entertaining the use of violence to attain much needed societal transformation. He was very confident (and as he would say, naïve) that proper intervention in the educational realm would be more than significant to improve the lot of the illiterate, the poor and the marginalized. What is needed is not revolutionary transformation but meaningful reforms in various social institutions particularly in the academic institution.

\section{Pedagogy of the Oppressed: Freire's Revolutionary Stance}

After his first major work and during the first years of Freire's exile, there was a radical development in Freire's thoughts. Holst describes it as "a relatively rapid change in Freire's educational philosophy." 19 Significantly influenced by his experiences in Chile, the place of his exile, Freire is now at home in using Marxian paradigms. Daniel Schugurensky says that "Pedagogy of the Oppressed reflected more clearly Freire's transition from a liberal, developmentalist approach to a more radical one that applied Marxist categories to the analysis of social and educational realities." ${ }^{20}$ Elias declares categorically that the "politics of Freire in Pedagogy and later writings is very different from the liberal democratic politics of Education for Critical Consciousness." 21

18 The above passage is from Paiva's 1978 Ph.D. Dissertation later on published as a book. The passage was cited by Celso de Rui Beisiegel and was quoted from Peter Lownd's Ph.D. Dissertation. See the following: Vanilda Pereira Paiva, Paulo Freire e o nacionalismodesenvolvimentista [Paulo Freire and Developmental Nationalism] (Rio de Janeiro: Civilização Brasileira, 1980); Celso de Rui Beiseigel, Política e Educação Popular. A Teoria e a Prática de Paulo Freire no Brasil [Politics and Popular Education: The Theory and Practice of Paulo Freire in Brazil] (São Paulo: Editora Ática, 1982), 174; Peter Lownds, In the Shadow of Freire: Popular Educators and Literacy in Northeast Brazil (Ph.D. Dissertation, Los Angeles, CA: University of California, 2005), 82.

${ }^{19}$ Holst, "Paulo Freire in Chile," 243.

${ }^{20}$ Schugurensky, Paulo Freire, 69.

${ }^{21}$ Elias, Freire: Pedagogue of Liberation, 42. 


\section{THE OVERCOMING OF VIOLENCE}

From this pivotal change, various Freirean commentators do not fail to see Freire's ready approval on the use of violent and armed struggles to achieve a more egalitarian societal structure. Stanley Grabowski, one of the early commentators of Freire, sees him to be proposing a pedagogy of revolution, understood as violent uprising. However, for Grabowski, more than a revolutionary, Freire is a prophet as he shakes up "the established way of doing things." 22 For William Griffith, an education professor at The University of Chicago, Freire's pedagogy is planned towards a political revolution and that Pedagogy of the Oppressed is committed to warrant a violent revolution. Griffith explains that in Freire's educational model, "the justification for conducting literacy training programs is the preparation of the learners to participate in the revolution to overthrow the oppressive elites." 23

For his part, Elias admits the humanist Marxism of Freire but he also sees Freire's ready approval of the "harsh elements of Marxism such as the class struggle and revolutionary violence." ${ }^{24}$ Collins already noted this when he said that "[Freire] was faulted by many readers for a too ready approval of revolutionary violence as the only solution to oppressive education." 25 Reacting to Ivan Illich's dubbing of Pedagogy of the Oppressed as a "truly revolutionary pedagogy," 26 another commentator, David Harmon, sees it rather as "pedagogy for revolution." 27 In another study, Rene Tadle of the University of Santo Tomas even argues for the possible reconciliation of violent revolution and Christian teaching about love, Freire's position on armed revolution meeting the criteria of traditional ethics' just war principle, and the importance of seeing revolution as a permanent process for social development and total human liberation. ${ }^{28}$

Furthermore, Dale and Hyslop-Margison suggest that Freire's notion of oppressor and oppressed are reflective of Marx's tension between the two main classes in the society. "Freire adopted the concepts of oppressor and oppressed from The Manifest of the Communist Party, and employed them as concrete examples of capitalism's tension between disparate economic

\footnotetext{
${ }^{22}$ Stanley Grabowski, Preface to Paulo Freire: A Revolutionary Dilemma for the Adult Educator (Syracuse: ERIC, 1972), iii.

${ }^{23}$ William Griffith, "Paulo Freire: Utopian Perspective on Literacy Education for Revolution," in Paulo Freire: A Revolutionary Dilemma, ed. by Stanley Grabowski, 71.

${ }^{24}$ Elias, Freire: Pedagogue of Liberation, 43.

${ }^{25}$ Denis Collins, Paulo Freire: His Life, Works and Thoughts (New York: Paulist, 1977), 20.

${ }^{26}$ Ivan Illich's cover endorsement for Paulo Freire's Pedagogy of the Oppressed.

27 David Harmon, "Methodology for Revolution," in Saturday Review, 54 (June 19, 1971). Quoted in Taylor, The Texts of Freire, 2.

${ }^{28}$ Rene Tadle, The Concept of Revolution by Paulo Freire (M.A. Thesis, Manila: University of Santo Tomas, 1991), 212-217. Tadle published his study in the journal Unitas. See Rene Luis Tadle, "Freire's Methodology and the Revolutionary Process," in Unitas, 66:1 (1993): 41-112.
}

(C) 2016 Franz Giueseppe F. Cortez

http://www.kritike.org/journal/issue_19/cortez_december2016.pdf ISSN 1908-7330

(cc) BY-NC-ND 
classes." 29 There is a tinge of validity in this observation because Freire himself says that Pedagogy of the Oppressed considers class tension as one of the important categories that should be considered in the educational process. ${ }^{30}$

Thus, it is not that difficult or even problematic to contend that Freire is readily supportive of violence as a means for social transformation. To be sure, Freire did not engage directly with any revolutionary struggle or armed combat. But when one opens the pages of Pedagogy of the Oppressed, the names of Marx, Fanon, Memmi, Guevarra, Lukacs, Kosik, Mao, and Luxembourg are quoted freely and prodigiously. The first mention of Karl Marx is in Extension or Communication, a long essay that Freire wrote when he was newly exiled in Chile. ${ }^{31}$ After which, almost all his writings are already replete with references from Marx and the Marxists. From Pedagogy of the Oppressed to Cultural Action for Freedom, from Letters to Guinnea-Bissau to The Politics of Education, from the talking books of the late 1980s to the final works of the mid-1990s, Karl Marx and some prominent Marxists are always referred.

As early as Education as the Practice of Freedom, Freire already criticizes the ideology behind the oppressor's use of violence accompanied with a seemingly God-given privilege to define it to the advantage of the oppressor class. He says:

Every relationship of domination, of exploitation, of oppression, is by definition violent, whether or not the violence is expressed by drastic means. In such a relationship, dominator and dominated alike are reduced to things - the former dehumanized by an excess of power, the latter by lack of it ....When the oppressed legitimately rise up against their oppressor, however, it is they who are usually labeled "violent," "barbaric," "inhuman," and "cold." Among the innumerable rights claimed by the dominating consciousness is the right to define violence, and to locate it. Oppressors never see themselves as violent. ${ }^{32}$

\footnotetext{
${ }^{29}$ John Dale and Emery Hyslop-Margison. Paulo Freire: Teaching for Freedom and Transformation (New York: Springer, 2010), 7.

${ }^{30}$ See Paulo Freire, Pedagogy of Hope: Reliving "Pedagogy of the Oppressed," trans. Robert Barr (New York: Continuum, 1995).

31 Paulo Freire, "Extension or Communication," in Freire, Education for Critical Consciousness, 144

${ }^{32}$ Freire, EPF, 10-11. However, since this passage is just in the footnote, most probably Freire only included this for the 1973 English publication where his educational politics was already obviously Marxist.
}

(C) 2016 Franz Giueseppe F. Cortez http://www.kritike.org/journal/issue_19/cortez_december2016.pdf ISSN 1908-7330 


\section{THE OVERCOMING OF VIOLENCE}

Then, we find Freire declaring in Pedagogy of the Oppressed that the revolutionary violence of the oppressed class is an act of love while that of the oppressor class is an act of dehumanization.

Yet it is - paradoxical though it may seem-precisely in the response of the oppressed to the violence of their oppressors that a gesture of love may be found. Consciously or unconsciously, the act of rebellion by the oppressed (an act which is always, or nearly always, as violent as the initial violence of the oppressors) can initiate love. Whereas the violence of the oppressors prevents the oppressed from being fully human, the response of the latter to this violence is grounded in the desire to pursue the right to be human. As the oppressors dehumanize others and violate their rights, they themselves also become dehumanized. As the oppressed, fighting to be human, take away the oppressors' power to dominate and suppress, they restore to the oppressors the humanity they had lost in the exercise of oppression. ${ }^{33}$

This is further reiterated in Pedagogy in Process when Freire concretely observes how the African revolutionaries of Guinea-Bissau dealt with utmost respect the apprehended enemies even if the latter showed harshness and cruelty. Freire concludes:

And this is a radical difference between the violence of the oppressor and the violence of the oppressed. That of the former is exercised in order to express the violence implicit in exploitation and domination. That of the latter is used to eliminate violence through the revolutionary transformation of the reality that makes it possible. ${ }^{34}$

Whether it is done with love, respect and full consideration of the humanity of the enemy, Freire seems to justify in specific circumstances the use of violence to attain genuine human liberation. This act of justification can easily be interpreted as ready approval of the said act.

\footnotetext{
${ }^{33}$ Paulo Freire, Pedagogy of the Oppressed, trans. by Myra Bergman Ramos (New York: Continuum, 1984), 41-42. Henceforth cited as, POO.

${ }^{34}$ Paulo Freire, Pedagogy in Process: The Letters to Guinea-Bissau (New York: Seabury Press, 1978), 34.

(C) 2016 Franz Giueseppe F. Cortez

http://www.kritike.org/journal/issue_19/cortez_december2016.pdf

ISSN 1908-7330

(c) BY-NC-ND
} 
In Education for Liberation, Freire sees the revolutionary action as the last remaining way of stopping exploitation, oppression and domination.

I am not an idealist. I think dialectically, historically. I have no illusion of going to the Wall Street and converting them to stop their exploitation of dependent societies because they must love people. Reality cannot be changed in our consciousness. It can only be changed historically through political action, through revolutionary action. ${ }^{35}$

The same tone of permissiveness to armed struggle can be deduced from his words in Pedagogy of the Oppressed. "They will not gain this liberation by chance but through the praxis of their quest for it, through their recognition of the necessity to fight for it. And this fight, because of the purpose given it by the oppressed, will actually constitute an act of love opposing the lovelessness which lies at the heart of the oppressor's violence, lovelessness even when clothed in false generosity." 36

For Freire, it is justifiable if the oppressed act violently against the oppressors because it is a response to the violence of the oppressor, it is in defense of the fundamental rights of the oppressed and it is motivated by love for humanity in general. The act of violence is never initiated by the oppressed. If ever they become violent, it is in reaction to the obvious or subtle violence by the oppressor. "Force is used not by those who have become weak under the preponderance of the strong, but by the strong who have emasculated them." 37

Even in his reflections on the role of the Church in the midst of an oppressive society, Freire does not refrain from airing his position regarding the validity of revolutionary action. "In truth, there is no humanization without liberation, just as there is no liberation without a revolutionary transformation of the class society, for in the class society all humanization is impossible. Liberation becomes concrete only when society is changed, not when its structures are simply modernized." 38

${ }^{35}$ Paulo Freire, Education for Liberation: Addresses by Paulo Freire and Critical Reflections on Indian Education (Bangalore: Ecumenical Christian Centre, 1975), 21.

${ }^{36}$ Freire, $P O O, 45$.

37 Ibid., 55-56.

38 Paulo Freire, "Education, Liberation and the Church," in Freire, The Politics of Education: Culture, Power, and Liberation, trans. by Donaldo Macedo (Connecticut: Bergin \& Garvey, 1985), 136.

(c) 2016 Franz Giueseppe F. Cortez http://www.kritike.org/journal/issue_19/cortez_december2016.pdf ISSN 1908-7330 


\section{THE OVERCOMING OF VIOLENCE}

Indeed, these citations render the mentioned commentators' observation that Freire, being a Marxist, is readily permissive of the use of armed struggles to attain meaningful changes in the society.

But Freire's thoughts especially on the issue of a violent power grab cannot be pinned down to his works during the 1960s and 1970s. Freire himself says that he is not Pedagogy of the Oppressed emphasizing that after this monumental book, his thoughts continue to evolve, and that he never stops doing an autocriticism. ${ }^{39}$ Schgurensky says that sometimes "it is assumed that Freire's ideas and those in Pedagogy of the Oppressed are one and the same, overlooking that in later works he criticized and revised some aspects of his earlier ones." 40 I contend, therefore, that one of the major modifications of Freire is regarding his idea of a violent power grab.

\section{The Rediscovery of Power: Freire's Critical Stance}

As early as Pedagogy of the Oppressed, Freire already manifests his nonabsolutizing tendency in endorsing an end-all and be-all form of action. $\mathrm{He}$ says:

Action and reflection occur simultaneously. A critical analysis of reality, may, however, reveal that a particular form of action is impossible or inappropriate at the present time. Those who through reflection perceive the infeasibility or inappropriateness of one or another form of action (which should accordingly be postponed or substituted) cannot thereby be accused of inaction. Critical reflection is also action. ${ }^{41}$

Here, we get a clue to Freire's openness to various forms of political action and struggle. His stress on the notion of praxis as the proper stance to avoid the extremes of blind activism and futile verbalism gives him the space not to consecrate armed revolution as the only effective means of transforming the oppressive societal arrangement.

Furthermore, in a 1975 essay, Freire reminds the progressive educators to become conscious of their limitations in order to avoid the extremes of pessimism and opportunism. "Throughout history one does what is historically possible and not what one would want to do." 42 Freire's

${ }^{39}$ Freire, "A Conversation with Paulo Freire," in Freire, The Politics of Education, 153.

${ }^{40}$ Schugurensky, Paulo Freire, 50.

${ }^{41}$ Freire, POO, 123.

${ }^{42}$ Freire, "An Invitation to Conscientization and Deschooling," in Freire, The Politics of Education, 171

(C) 2016 Franz Giueseppe F. Cortez

http://www.kritike.org/journal/issue_19/cortez_december2016.pdf

ISSN 1908-7330

(c) ) BY-NC-ND 
continual critical stance manifests his stress on actions that are motivated by critical reflection and not by merely blind emotivism.

The more telling sign of this important development in his thought can be found in an interview he had with Macedo, published as part of the 1985 book, The Politics of Education. Here, Freire starts to entertain the idea of the incomprehensibility of the taking of power from the dominant group and the State and the possibility of reinventing power itself through the various social movements. He explains to Macedo: "Because I am extremely concerned with and see a vital role for subjectivity and consciousness in the making of history, I now feel that in transforming society, the important task is not to take power but to reinvent power." 43

Some three years later in Learning to Question, his conversational book with Antonio Faundez, the same theme of the reinvention of power is brought to the fore. Here, Freire had more opportunity to elaborate what he means by this reinvention. He observes:

I am convinced that we are experiencing and being confronted with certain challenges which in the closing years of this century are coming over very strongly .... One of these issues is power: the question of power. I am quite sure that the basic problem facing us today in the struggle to change society is not that of simply gaining power, but a gaining of power which is prolonged creatively in a rediscovery of power; creating a new power which does not fear to be called in question and does not become rigid for the sake of defending the freedom already achieved which, basically, should be a freedom constantly being achieved. ${ }^{44}$

As a response to this, Faundez sees the significance of raising the important questions of the meaning, location and possessor of power. He argues that the State or any single institution is not the sole locus of power. Faundez explains:

I regard the state-its administration, its coercive power, and its ideological apparatus - as the point from which power is distributed. Thus teachers, educationalists and politicians possess a portion of power because they

\footnotetext{
${ }^{43}$ Freire, "Rethinking Critical Pedagogy: A Dialogue with Paulo Freire," in The Politics of Education, 179.

${ }^{44}$ Paulo Freire and Antonio Faundez, Learning to Question: A Pedagogy for Liberation (New York: Continuum, 1989), 63-64.
}

(c) 2016 Franz Giueseppe F. Cortez http://www.kritike.org/journal/issue_19/cortez_december2016.pdf ISSN 1908-7330 
receive it from the state. There is a hierarchy of power. Beginning from the state, power becomes diluted, and the state entrusts a portion of power to each one, while the classes at the top of the state hierarchy maintain their position as those who possess the greatest power of all: the power to confer power. However, to identify power with the state, and so lay down that in order to change society you must begin by taking over the power of the state (since state and power are identical) is a mistake epistemologically, politically and even psychologically. 45

Freire agrees with Faundez and in the practical level, he sees the important role of social movements and organizations united for specific social causes such as ecology, women's rights and others.

Hence, in subsequent books, Freire is freer to express openly that his pedagogy is not meant to instigate violent revolution and to effect earthshaking and grand societal changes. In Pedagogy of Freedom, he explains this clearly.

... it is not a question of inciting the exploited poor to rebellion, to mobilization, to organization, to shaking up the world. In truth, it's a question of working in some given area, be it literacy, health, or evangelization, and doing so as to awake the conscience of each group, in a constructive, critical manner, about the violence and extreme injustice of this concrete situation. Even further, to make it clear that this situation is not the immutable will of God. ${ }^{46}$

Thus, with regard to a violent class struggle in the attainment of a transformed society, Freire reconsiders his position because of his firm conviction to respect human agency and subjectivity. It is probably on this line of thinking that Macedo and Araujo-Freire categorically say that Freire does not endorse violence as a way of attaining human liberation and social transformation.

${ }^{45}$ Ibid., 63.

${ }^{46}$ Paulo Freire, Pedagogy of Freedom: Ethics, Democracy and Civic Courage (Maryland: Rowman \& Littlefield Publishers, 1998), 55.

(C) 2016 Franz Giueseppe F. Cortez

http://www.kritike.org/journal/issue_19/cortez_december2016.pdf

ISSN 1908-7330

(c) $\mathrm{BY}-\mathrm{NC}-\mathrm{ND}$ 


\section{Concluding Remarks}

Does Paulo Freire advocate violence as a means to attain meaningful social transformation? Even if there are statements such as those of Macedo, Araujo-Freire and McLaren, I believe that this question cannot be answered accurately by a simple "yes" or "no." Rather, inasmuch as reality is always in flux, Freire must also be read as a thinker whose ideas cannot be frozen in time, who was an active participant of history, and who is ever sensitive to the fluidity of history. He once said in a response to some essays written about him: "My thinking has been evolving, and I have been constantly learning from others throughout the world." 47

The starting point of this evolution of his educational and political thinking is mainly reflected in his first book Education as the Practice of Freedom where he is convinced that social transformation follows smoothly from a conscientized populace. ${ }^{48} \mathrm{He}$ later admits of the naïveté of this position. ${ }^{49}$ The next turning point is expressed lucidly in the pages of Pedagogy of the Oppressed where he is radical in saying that reality is not changed by changing the consciousness but by deliberately acting to change that reality. The use of violence cannot be discarded as a remote possibility. Finally, in Learning to Question, social transformation is not only gained by taking of power of the state because power permeates in the diverse elements of the state itself. In other words, power is located in small and probably, unexpected spaces. The critical educator must be sensitive enough to locate, recognize, communicate and grab those cracks and openings.

The development of Freire's thought reaches a point which I would call as "a progressive return." There is a kind of return because the "later Freire" talks again of the priority of the development of human consciousness. It is progressive because it represents the overcoming of double naïveté: that society can never be changed by simply changing the consciousness through the school and that society today can never be assured to change by and through a violent power-grab. Rather, what is necessary is

${ }^{47}$ Paulo Freire, "A Response," in Mentoring the Mentor: A Critical Dialogue with Paulo Freire, ed. by P. Freire, J. Fraser, D. Macedo, T. McKinnon, and W. Stokes (New York: Peter Lang, 1997), 312.

48 "It so happens that to every understanding, sooner or later an action corresponds. Once man perceives a challenge, understands it, and recognizes the possibilities of response, he acts. The nature of that action corresponds to the nature of his understanding." Freire, EPF, 44.

49 "I feel I should make a few more points. One would be a self-criticism, based on my Education as Practice of Liberation, for thinking that in the process of conscientization the moment of revealing a social reality is a kind of psychological motivation for its transformation...It was as though to unveil reality guaranteed that it was already being transformed." Freire, "An Invitation to Conscientization and Deschooling," in The Politics of Education, 169.

(C) 2016 Franz Giueseppe F. Cortez http://www.kritike.org/journal/issue_19/cortez_december2016.pdf ISSN 1908-7330 


\section{THE OVERCOMING OF VIOLENCE}

a persistent rediscovery of the location of power in small spaces and its intensification and recognition through renewed critical pedagogy.

Department of Philosophy, University of Santo Tomas, Philippines

\section{References}

Araujo-Freire, Ana Maria and Donaldo Macedo, Introduction to Paulo Freire, The Paulo Freire Reader, ed. by Ana Maria Araujo-Freire and Donaldo Macedo (New York: Continuum, 1998).

Aronson, Ronald, After Marxism (London: Guilford Press, 1995).

Beiseigel, Celso de Rui, Política e Educação Popular. A Teoria e a Prática de Paulo Freire no Brasil [Politics and Popular Education: The Theory and Practice of Paulo Freire in Brazil] (São Paulo: Editora Ática, 1982).

Brookfield, Stephen, The Power of Critical Theory for Adult Learning and Teaching (New York: Open University Press, 2005).

Cortez, F.G.F., “The Philippine Engagement with Paulo Freire," in Kritike, 7:2 (2013)

"The Prospect of Liberating Pedagogy in the Thoughts of Amable G. Tuibeo," in Mabini Review, 3:1 (2014).

Towards a Freirean Liberating Pedagogy in the Philippines: Prospects in Three Filipino Intellectuals (Ph.D. Dissertation, Manila: University of Santo Tomas, 2013).

Collins, Denis, Paulo Freire: His Life, Works and Thoughts (New York: Paulist, 1977).

Dale, John and Emery Hyslop-Margison. Paulo Freire: Teaching for Freedom and Transformation (New York: Springer, 2010).

Elias, John, Paulo Freire: Pedagogue of Liberation (Florida: Krieger, 1994).

Freire, Paulo, in Education for Critical Consciousness, trans. by Myra Bergman Ramos (New York: The Seabury Press, 1973).

Education for Liberation: Addresses by Paulo Freire and Critical Reflections on Indian Education (Bangalore: Ecumenical Christian Centre, 1975).

Pedagogy in Process: The Letters to Guinea-Bissau (New York: Seabury Press, 1978).

- Pedagogy of Freedom: Ethics, Democracy and Civic Courage

(Maryland: Rowman \& Littlefield Publishers, 1998).

Pedagogy of Hope: Reliving "Pedagogy of the Oppressed," trans.

Robert Barr (New York: Continuum, 1995).

Pedagogy of the Oppressed, trans. by Myra Bergman Ramos (New

York: Continuum, 1984).

(C) 2016 Franz Giueseppe F. Cortez

http://www.kritike.org/journal/issue_19/cortez_december2016.pdf

ISSN 1908-7330

(c) ) BY-NC-ND 
The Politics of Education: Culture, Power, and Liberation, trans. by Donaldo Macedo (Connecticut: Bergin \& Garvey, 1985).

Freire, Paulo and Antonio Faundez, Learning to Question: A Pedagogy for Liberation (New York: Continuum, 1989).

Freire, Paulo, James Fraser, Donaldo Macedo, Tanya McKinnon, and William Stokes, eds., Mentoring the Mentor: A Critical Dialogue with Paulo Freire (New York: Peter Lang, 1997).

Gouldner, Alvin, The Two Marxisms: Contradictions and Anomalies in the Development of Theory (New York: The Seabury Press, 1980).

Grabowski, Stanley, ed., Paulo Freire: A Revolutionary Dilemma for the Adult Educator (Syracuse: ERIC, 1972).

Griffith, William, "Paulo Freire: Utopian Perspective on Literacy Education for Revolution," in Paulo Freire: A Revolutionary Dilemma for the Adult Educator, ed. by Stanley Grabowski (Syracuse: ERIC, 1972).

Harmon, David, "Methodology for Revolution," in Saturday Review, 54 (June 19, 1971).

Holst, John, "Paulo Freire in Chile, 1964-1969: Pedagogy of the Oppressed in Its Sociopolitical Economic Context," in Harvard Educational Review, 76 (2006).

Lownds, Peter, In the Shadow of Freire: Popular Educators and Literacy in Northeast Brazil (Ph.D. Dissertation, Los Angeles, CA: University of California, 2005).

McLaren, Peter, Che Guevara, Paulo Freire, and the Pedagogy of Revolution (Lanham: Rowman \& Littlefield Publishers, 2000).

Life in Schools: An Introduction to Critical Pedagogy in the Foundations of Education, 3rd ed. (New York: Longman, 1997).

Ojoy, Virgilio Abad, Marxism and Religion: A Fusion of Horizons: A Discourse on Gustavo Gutierrez's Theology of Liberation and the Philippines' Church of the Poor (Manila, Philippines: UST Publishing House, 2001).

Paiva, Vanilda Pereira, Paulo Freire e o nacionalismo-desenvolvimentista [Paulo Freire and Developmental Nationalism] (Rio de Janeiro: Civilização Brasileira, 1980).

Rockmore, Tom, Marx after Marxism: The Philosophy of Karl Marx (Oxford: Blackwell Publishers Ltd., 2002).

Schugurensky, Daniel, Paulo Freire (London: Continuum, 2011).

Tadle, Rene, "Freire's Methodology and the Revolutionary Process," in Unitas, 66:1 (1993).

The Concept of Revolution by Paulo Freire (M.A. Thesis, Manila: University of Santo Tomas, 1991).

Taylor, Paul V. The Texts of Paulo Freire (Philadelphia: Open University Press, 1993).

Worsley, Peter, Marx and Marxism (London: Routledge, 2002).

(c) 2016 Franz Giueseppe F. Cortez

http://www.kritike.org/journal/issue_19/cortez_december2016.pdf

ISSN 1908-7330 